\title{
In search of our human face: Black consciousness, black spirituality, inclusive humanity and the politics of vulgarity
}

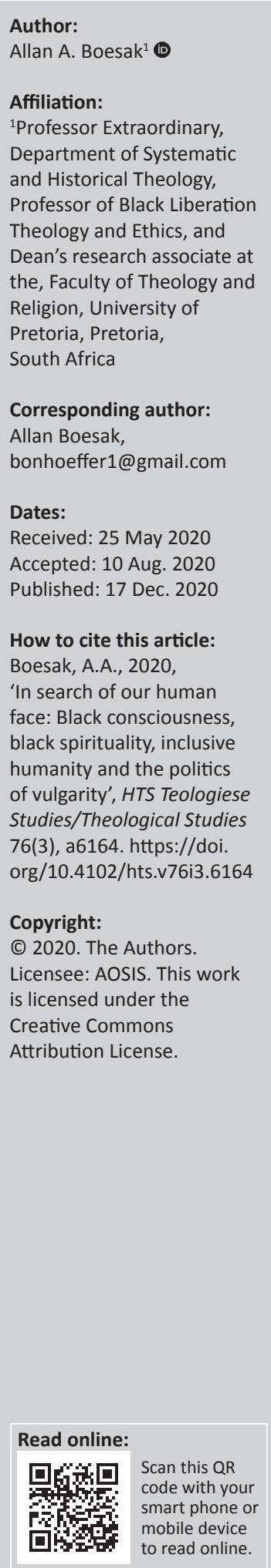

This contribution grapples with the question: Is there a relationship between Steve Biko's 'quest for a true humanity' or, differently put, his search for South Africa's 'human face' and Vuyani Vellem's quest for an African spirituality? Our proposition is that there is such a relationship. This discussion is framed overall by two other questions: What is the relevance of this 'quest' within the present South African context, what is its contribution to the global situation and, fundamentally, what is the contribution black liberation theology can make to these discourses? In the course of this exploration, we engage the concepts of Africanisation and Afrocentricity, colonisation, coloniality and decoloniality, and we ask whether a true Afro-pluralism is possible without a true African indigeneity. These concepts, we shall argue, are tools of struggle, not only in confronting colonisation and coloniality but also in battling imperialism, in the form I discuss here: the politics of vulgarity. I contend that an African spirituality, Biko's 'gift' from Africa to the world, is the most appropriate vessel for that very gift.

Contribution: This article serves as commemoration of the contribution the late Professor Vuyani Vellem made to the qualitative substantiation of black theology liberation in South Africa. It demonstrates the powerful way in which Afro-pluralism enhances the contranarrative of imperialism and colonialism.

Keywords: black consciousness; black liberation theology; Africanisation; Afrocentricity; Afro-plurality; indigeneity; humanism; politics of vulgarity; spirituality.

\section{The quest for true humanity}

Throughout his work, Vuyani Vellem was captivated by African spirituality, the necessity of it, the reality of it, the void its absence leaves in our hearts, the church and in the workings of our society, the healing power of it. From a separate section in his 2007 Ph.D dissertation (Vellem 2007), he created a splendid article, engaging Charles Villa-Vicencio's 'project of reconstruction', in detail, a crucial debate at the time. There, the critique, perhaps even confrontation, is explicit. The title of that article is a combative juxtaposition: 'Ideology and Spirituality' (Vellem 2010). Over time, he has returned to it in different ways. The question I would want to explore in this article is this: Is Vellem's search for an African spirituality the same as Biko's search for our human face? What does searching for, and attaining, our human face mean for South Africa today?

'We have set out on a quest for true humanity', said Steve Biko in an early 1970 essay, his contribution to South Africa's very first anthology on black liberation theology, and somewhere on the distant horizon, we can see the glittering prize. Let us march forth with courage and determination, drawing from our common plight ... and our brotherhood [and sisterhood]. In time, we shall be in a position to bestow upon South Africa the greatest gift possible - a more human face (Biko 2017:108).

I regard this as arguably one of the most crucial insights from Biko's considerable wisdom and one vital for our developing and maturing understanding of our situation today. To begin with, the bracketed words in the given quote, 'and sisterhood', indicate wholehearted concurrence with feminist critique of Biko's, and perhaps of all male thinking on black consciousness on the question

Special Collection: Special Collection entitled VukaniBantuTsohangBatho - Spirituality of Black Liberation, sub-edited by Fundiswa Kobo (UNISA) and Rothney Tshaka (UNISA). 
of gender, equality, justice and respect for the dignity of women. Sociologist Zimitri Erasmus (University of the Witwatersrand) (2018:53-68) wrote of Biko: 'He addresses black men and white people of liberal persuasion, but he excludes black women. Thus, he leaves untouched the humiliations and injustices of gendered hierarchies' (Erasmus 2018:59). She is absolutely correct. It is a shortcoming we have to admit and a mea culpa we have to express and work much harder to eliminate. I have pointed out this issue several times, making the argument that as black males, we may have been converted from our sexism, but we have yet to overcome our patriarchalism (Boesak 2019).

In reflecting on Biko's search for our human face, I need to underscore three further points here. Firstly, Erasmus has full appreciation for what she calls Biko's 'humanism'. She mentions some examples: his assertion that blacks are not 'an extension of a broom or an additional leverage to a machine'. His insight is that 'beyond material well-being the fact of being human should be the centre of our social and political concern'. The fact that it is through these 'material and spiritual projects' that blacks will be able to 'give the world a more human face' (2018:58). Nonetheless, she worries about 'moments' when he locates his humanism in a romanticised construction of African culture as 'pure', 'close to nature', characterised by beliefs in the 'inherent goodness of man' (2018:59).

Again, Erasmus is correct, and in the current, heated debates on decolonisation, decoloniality, Africanisation and Africanity there is such a marked re-appreciation of these concepts in black consciousness and Biko's thought that the warning seems appropriate. I will argue that Biko's 'human face' was never intended to be confined to 'blackness' as 'racial' category and that his political understanding of blackness was always an inclusive Africanness. This is already illustrated in his understanding of the concept of 'black solidarity'. ${ }^{1}$ (Biko 2017:56). It is a conscious effort to overcome the hegemonies of race and ethnicity imposed upon us by apartheid. Within this context, Biko (2017) encouraged all of us - those categorised, dehumanised and racially designated by apartheid's racialised obsessions - to understand liberation as of:

Paramount importance in the concept of Black Consciousness, for we cannot be conscious of ourselves and yet remain in bondage. We want to attain the envisioned self, which is a free self. (p. 53)

That freedom, I suggest, was the freedom to express ourselves as 'complete in ourselves' by which I mean completely and fully human, a concept we will further explore here. From a Christian point of view, firstly, that 'envisioned self' was grounded in our being created in the image of God, 'in our

1.Biko (2017) writes, Being black is not a matter of pigmentation - being black is reflection of a mental attitude' (p. 52). The apartheid-created and apartheid-serving determinations ('Bantus', 'mixed race', 'Indians', etc.), as well as the apartheidinduced associations of apartness, racial and ethnic validity in relation to 'whiteness', and rivalry (as related to apartheid's pigmentocratic scale of status, acceptability and privileges) should be resisted, discarded and destroyed. What we 'should at all and privileges) should be resisted, discarded and destroyed. What we 'should at a times look at is that 'we are all oppressed by the same system' and that 'by varyin degrees' (p. 56) to create and increase division and tensions within the oppressed communities. It is a 'deliberate ploy to stratify' us and should be exposed as 'the God's 'deliberateness to cryate black people black' (p. 53). That is to say, God's God's 'deliberateness to create black people black' (p. 53). That is to say, God's deliberate intention to declare blackness God's complete created humanness, captured in the divine satisfaction: 'And indeed, it was very good' (Gn 1:31). likeness', says God (Gn 1:26), not an 'aberration from the "normal" which is white" (Biko 2017:53). Secondly, it is grounded in the incarnation God in Christ who became human and identified completely with us. The Bible is even more specific. He not only took on human form, but the form of a slave, identifying with what was regarded the lowest of the low (Phlp 2:6-8). But it is as the despised one that he is proclaimed Child of God, 'Lord' and Saviour. That is the grounds for true equality because it is the obliteration of all induced inferiority and false sense of superiority. This consciousness is the only true basis of non-racialism and is the foundation upon which the true egalitarian society, as Biko (2017:169) would have it, must be built. It was on this philosophical basis that the United Democratic Front was founded as a truly non-racial, inclusive movement (Boesak 2009:Introduction).

It remains an important insight for the debates today as we struggle for the recovery of African humanity against the ravages of Eurocentrism and coloniality. Let us consider one example. At the core of Unisa's Simphiwe Sesanti's discussion on these matters is the argument that tapping into (subjugated) African knowledge is essential to dismantling neocolonialism in education and other spheres. For him, in this process, Afrocentrism is the absolute key. Sesanti speaks of an almost universal, historically unbroken African culture as 'central' to an Afrocentric education. Afrocentricity is:

A philosophical perspective associated with the discovery, location, and actualizing of African agency within the context of history and culture ... a quality of thought and practice rooted in the cultural and human interests of African people. (Sesanti 2016:35)

Afrocentricity is interested in what Africans traditionally regarded best in education before colonial invasion (Sesanti 2016:35).

Sesanti pleads for a return to 'African concepts' such as Ubuntu, and 'traditional African precepts' such as the seSotho proverb feta kgomo o tshwaremotho, which 'informed Africans' approach to economics, the giving of compassion', and the work towards the 'elimination of poverty, criminality and greed' (2016:36).

The issue here is not that these values actually existed (and hopefully still do) in various African communities. Neither is it that these values can indeed make the kind of spiritual and material contribution towards giving the world 'a human face'. I have argued in this same vein in my first writings some 40 years ago, yet also cautioning (although with hindsight that caution was far too muted) that we should not uncritically accept everything that purports to be 'African culture' (Boesak 1976:142ff.) and later argued for a serious problematising of concepts such as Ubuntu (Boesak 2017:ch. 4). Cautioning against 'a romanticised construction of African culture' as Erasmus does, is entirely appropriate.

But that is not the only question at issue here. Michael Nassen Smith and Tafadzwa Tivaringe have problems not only with the assumption that the values Sesanti advocates will assist 2.We return to the phrase 'envisioned self' later on in this article. 
in the fight for decoloniality and an African renaissance because they are 'Afrocentric'. They take even more issue with Sesanti's implication that 'there is, and has always been, one unique African culture, distinct from European and other cultures to which an Afrocentric academy should attend' (Smith \& Tivaringe 2016:41-43). These are values, they argue, that are shared by other cultures as well. The desire for the preservation of human life as preference over the accumulation and preservation of wealth for instance is not uniquely African. 'Such a statement may have been made by Jesus or Lao Tzu' (2016:42).

Smith and Tivaringe (2016) do not deny the suppression of African traditions and epistemologies as a fact of history and that it produces a 'normative injunction':

How are we, as Africans, to rehabilitate indigenous thought in a way that speaks to local histories and particularities while also meeting the concrete challenges that the continent faces in today's hyper-globalised political economy? This is the historic mission of our time. (p. 41)

For our needs today however, they insist, and in order to meet the call of this historic mission, Afro-centrism is not the proper solution. They fear that in doing so, 'instead of dismantling the colonial imaginary, Sesanti (2016:43) in fact implicitly supports it'. Hence, we must be careful of merely 'reproducing colonial binaries and Manichean thinking'. Instead of an untroubled Afrocentricity, they argue that a 'shift of focus or attention is needed, a shift towards a decolonial humanism and an Afro-plurality ...' (2016:43). Instead of searching after an African purity, we should welcome its diversity and not unwittingly contribute to colonialism's binaries.

Sesanti does try to avoid the dangers of 'a romanticised construction of African culture' against which Erasmus cautions. And that shows his awareness of Biko's self-critical consciousness. The picture that accompanies Sesanti's piece shows him in a T-shirt with Steve Biko's face on the front. So the association is clear, and it is also detectable in (the spirit of) his choice of words even though he does not quote Biko directly:

Against this Eurocentric trajectory, Afrocentric education seeks to rediscover the true history of Africans - the good and the bad, successes and failures - so as to inspire and also to warn Africans against pitfalls. More specifically, it seeks to reclaim those values [....] to sensitise Africans about the importance of not only reclaiming economic power, without which they cannot do much, but also reclaim their ancestral values for educational purposes so as to build not only a human Africa, but a humane world. (Sesanti 2016:40)

I am in agreement with Sesanti when he posits that the aim of all our work should indeed be that striving towards that gift of a human face for Africa and the world. And whilst Sesanti's Bikonian self-critical awareness is clear and highly laudable, it seems to me that if our aim is to remain true to Biko's legacy - perhaps especially in truthfully following the logic of his thinking whilst confronting the challenges of race, ethnicity and nationalism as they present themselves in our time - we should think more carefully about the forms our resistance to Eurocentrism should take. So, our 'ancestral values' should be more vigorously interrogated. Are what many Africans regard, and sometimes defend as 'traditional values', for example about the place of women in society, or the acceptance of the dignity of LGBTQI persons to be uncritically embraced? At the very least, critical discernment is called for here.

Our 'historic moment' is a time of still-unconquered imperialism, ongoing colonialism, renewed racism and the temptations of all sorts of harmful self-preservations - the fertile soil of exclusivism and 'othering' - and we would be wise to seriously consider the 'shift of focus' Smith and Tivaringe propose. So perhaps the wisdom of an African plurality and a decolonial humanism would be more true to Biko's quest for a human face for the world as we wrestle with his thinking in our times. Smith and Tivaringe wrote (2016):

Our continent is home to millions of people of different races, different languages, different belief systems and different traditions. Black, white, Arab, Asian, mixed-race, gay, straight, queer, Christian, Muslim, Hindu, Buddhist, San, Zulu, Maasai ... Exactly how much of our history and today's human resources are we willing to discard in a stubborn search for Afro-purity? (p. 43)

These two young researchers have opened up points for valuable discussion and it is exactly what is needed as we continue to explore 'the historic mission' in our times. A shift of focus should be firmly on our agenda. Yet questions remain. At least for now. Why are Afro-centricity and Afro-plurality posited as mutually exclusive? And further, taking a 'decolonised' humanism seriously, why is (African) indigeneity, as a much more emphatically inclusive concept and practice not considered a (better) concept for serving these goals? In South Africa's new, not only racialised, but ethnicised realities and debates, South Africa's first nations, its indigenes and their pre-1652 existence, realities and lived experiences, are almost always left out of the equation, and mostly this is an act of political expedience, where the descendants of these indigenous peoples must constantly fight for the right to be 'African'. ${ }^{3}$ But it is not serving the desire for a decolonised humanism. When Biko writes that it is the task of black consciousness to correct the lie that 'South Africa's history began in 1652', it is not simply an observation. It is the acceptance of a foundational truth, without which our decolonised humanism will never be whole. Why can both (Afro-plurality and Afro-centricity), as agents of indigeneity, not serve the struggle for a 'de-colonised humanism'?

The struggle against Euro-centricity in all its many manifestations is real. As real is the necessity of resistance against the suppression of African histories, traditions and epistemologies. In fact, 'epistemecide', like genocide, is not at all hyperbole, and the seriousness of this historical situation should not be trivialised under the weight of academic purity.

3.See the discussion on these sometimes furious, but infinitely important contemporary debates and the reference to the insightful views of Patric Tariq Mellet in Allan Boesak (2019:212-214). 
Boaventura de Sousa Santos' widely recognised description still stands (in Paraskewa 2016):

Epistemicide is the murder of knowledge. Unequal exchanges among cultures always implied the death of the knowledge of the subordinated culture, hence the death of the subordinated groups that possessed it. In the most extreme cases, such as the European expansion, epistemicide was one of the conditions of the genocide. The loss of epistimelogical confidence that currently afflicts modern science has facilitated the identification of the scope and gravity of the epistemicides perpetrated by hegemonic Eurocentric modernity. (p. 2)

'Euro-centricity' does indeed capture this accurately, and it should remain the focus of these new struggles provided that we take the critical and self-critical elements in black consciousness and spirituality seriously. I should think that Afro-centricity and Afro-plurality together as agents of indigeneity, the recovery and rediscovering, the gathering and harnessing of all our resources in all of their diversities and pluralities, would be a formidable force in the struggle not only for the decolonised African mind but also for a decolonial humanism.

\section{'Full humanity requires freedom'}

I should make a second point. As I read Biko, his idea of the 'human face' equals John Calvin's concept of 'full humanity'. 'Full humanity requires liberty', Calvin writes in his commentary on Matthew 2:9. Calvin understood that full humanity, that is, meaningful and purposeful life as free children of God endowed with inalienable rights to worthiness, justice, equity, having choices and dignity, cannot be realised whilst people are viciously oppressed or remain in the chains of social hesitation, economic deprivation and political ambiguity. It requires freedom. Full humanity, not 'three-fifths of a person' as the Constitution of the United States to this day describes Americans of African descent, with 'no rights which the white man is bound to respect', as the scandalous 1857 Dred Scott U.S. Supreme Court decision declared. And the consequences of that mindset, wrote Walter Johnson (2017), are palpable in the mindless havoc racism and white supremacist nationalism are causing in that country even as I write. ${ }^{4}$

Calvin insists on full humanity, not 'once born', 'broken', 'split', or 'burnt' outcaste as the Dalits of India are designated (Human Rights Watch 1999:1, 2). Not 'creatures', English for 'skepsels' as white South Africans used to call us and describe us in their Afrikaans dictionaries to make sure that on the farms and on the streets, in school and in church, in formal speeches and casual conversations this is drilled into us:

4.The consequences of that infamous 'Dred Scott decision', argues Harvard University historian Walter Johnson, are impacting African Americans to this day. When Dred Scott filed his case in the Missouri Courts in 1846, he was on good legal footing 'However, the colour of his skin prohibited him from being seen by the court as citizen of the United States with rights to claim. More than a century after the Dred Scott decision argued that black people lived in Missouri by the grace of white police state'.

5.It is perhaps not altogether surprising that Dalits themselves are referring to their situation as one of 'apartheid'. See, for example, Sathianathan Clarke's reference to situation as one of 'apartheid'. See, for example, Sathianathan Clarke's reference to Theological Exposition' (Clarke, Manchala \& Peacock, eds. 2017:17). creatures, 'non-whites' who are considered less worthy, less trustworthy, less deserving, less human. So, Biko is saying, South Africa will have acquired that human face only when all its people have acquired full humanity.

Full humanity, not a situation where 'race' determines one's acceptability to the human community or where the poor are tolerated yet exploited, because they will 'always be amongst us' (and remain a source of cheap labour). Or where women are tolerated yet abused, because they are 'the weaker sex' (but necessary for procreation and service to men); or where LGBTQI+ persons are tolerated despite their sexual orientation, yet despised and discriminated against, because we 'hate the sin, but love the sinner' (and that strokes our sense of moral superiority). Full humanity, treated, accepted and honoured with indivisible justice, inclusive dignity and unqualified equality. Full humanity - a life not touched, ruled and poisoned by fear, which Biko (2017:73-79) called a soul destroying force.

But full humanity, is John Calvin's firm conviction, 'requires freedom'. Requires, not desires, not merely longed for or requested and certainly not begged for. This means struggle, however, for full humanity does not flourish in situations of oppression, injustice, discrimination, dehumanisation and indignity. Conversely, this is the result of a freedom defined by the oppressed and the powerless themselves, not the scraps that are thrown from the table of the privileged who think that their power justifies their sacralised dominance.

The quest for true humanity is inextricable from the struggle for justice, dignity, equity and freedom. That is why, on numerous occasions, Calvin speaks of tyranny, that is, political oppression, economic exploitation and dehumanisation through unjust laws and practices, as totally unacceptable, as rebellion against God, a denial of the rights of the powerless and a denigration of the rights of God. And that is why Calvin (1981) insists that to not rise up in resistance against that oppression is 'cowardice'; rising up against it is a sacred duty $^{6}$ (Mt 2:9-10).

Biko is not naïve; however, he knows that it is a struggle and that we are in it for the duration. Biko (2017:170) foresaw what post-1994 South Africans are now having to come to terms with: the end of official apartheid and a black face in high office would not mean the end of that struggle. He spoke of the 'distant horizon' not in an effort to discourage and certainly not in a spirit of defeat in the face of apartheid's formidable might. Biko spoke with clarity of mind, from a deep, experiential understanding of the nature, durability and adaptability of evil, a truth we learned from Henry Highland Garnet, Albert John Mvumbi Luthuli and Martin Luther King Jr., namely that power is never surrendered voluntarily. It has to be wrested from the hands of the oppressor.

6.Calvin writes, Only a degraded people could prefer the yoke of tyranny to the inconveniences of change'. And in his commentary on Isaiah 3:12 Calvin is explicit: inconveniences of change'. And in his commentary on Isaiah 3:12 Calvin is explicit:
'There is no doubt that God has struck with a spirit of cowardice those who, like asses, willingly offer their shoulders for burdens'. 
Long ago, the 19th century African American abolitionist, literary giant and freedom fighter Frederick Douglass made it clear in his incomparable way (Douglass 1857):

If there is no struggle, there is no progress. Those who profess to favor freedom and yet deprecate agitation are men who want crops without plowing up the ground; they want rain without thunder and lightning. They want the ocean without the awful roar of its many waters. The struggle may be a moral one, or it may be a physical one, and it may be both moral and physical, but it must be a struggle. Power concedes nothing without a demand. It never did and it never will....The limits of tyrants are prescribed by the endurance of those whom they oppress.

Biko (2017:97-99), who had in fact quoted Douglass on this issue, ${ }^{7}$ broke the literary flourish down, telling South Africans in plain language what this practically meant (2017):

In a true bid for change we have to take off our coats, be prepared to lose our comfort and security, our jobs, and positions of prestige, and our families, for just as it is true that 'leadership and security are basically incompatible', a struggle without casualties is not struggle. ${ }^{8}$ (p. 97)

At this point in our history, reaching the realisation of Biko's dream still remains South Africa's greatest challenge. This dream, which Biko saw 'far, on the distant horizon', is still distant. For all our challenges - the grim, continuous impoverishment of the vast majority of our people, the unconscionable gap between rich and poor, our unconquered racism, our stuttering social cohesion, the tragic failures of our reconciliation process, our battles with crime and corruption, our utterly shameful gender-based violence, bigotry, misogyny and homophobia and the bewildering brutality of South Africans against each other - are captured in the longing for our country to have 'a more human face'.

Biko said this in the midst of a struggle against one of the most inhumane systems the world has ever known, labelled a 'crime against humanity' by the international community. Apartheid was a vicious, violent, totalitarian system, not just in the unsurpassed draconian nature of its laws and their application but in the totality of its claims upon every area in the lives of the oppressed. Now we have to recall Biko's words, for 25 years into our democratic experiment, this struggle for indivisible justice, human dignity and inclusive humanity is still not over, and the poor, women and the LGBTQI+ communities are bearing the brunt of it.

\section{The politics of vulgarity}

Black consciousness, as the search for a human face, is a global struggle, 'the most positive call to emanate from the black world for a long time'. It seems it is time for that call, as a call for the discovery, and embrace of our essential humanness and worthiness, to resound again. Slovenian sociologist and philosopher Slavoj Žižek (2016) spoke of

7.The words, "We must expect that the limits of tyrants are prescribed by the endurance of those whom they oppress' (see p. 100), are directly from Douglass as the above citation shows, even though Biko does not credit him. Biko does not make use of footnotes in this publication.

8.I Write What I Like, p. 108. 'public vulgarity' rampant on the world stage today. Žižek means, of course, especially Donald Trump and his vulgar language, the way Trump brags about his sexual assaults on women, his racist talk about Mexicans, Africans and other people of colour, his denigration of vulnerable groups, his homophobia and misogyny and his justification and encouragement of violent, white supremacies.

As equally guilty as Trump, Žižek says, is Israeli Prime Minister Benjamin Netanyahu. Netanyahu has referred to an unverified exchange between Adolf Hitler and Haj al-Husseini, the grand mufti of Jerusalem, in which, he claims - in his constant efforts to demonise Palestinians - that it was al-Husseini who persuaded Hitler to kill the Jews, when Hitler seemed only willing to deport them. Even knowing the depths to which Netanyahu regularly sinks in his denigration of Palestinians, this goes particularly far. But, says Žižek (2016):

We should be under no illusions about the meaning of statements like those of Netanyahu. They are a clear sign of the regression of our public sphere. Associations and ideas that were till now confined to the obscure underworld of racist obscenity are now gaining a foothold on official discourse.

This is even more striking when one keeps in mind the way that Trump has mocked 'political correctness' and virtually made it the language of 'sissies', those not brave enough to say openly what they think and believe deep down, a truly perverse inversion of 'speaking truth to power'. This is not only gaining new ground for vulgarity, it is simultaneously an effort to render useless victories painstakingly won. Žižek (2016) correctly sees how language breeds, justifies and legitimises violence, as in the case of torture encouraged and practiced by the George W. Bush administration:

The language of vulgarity and brutal violence practiced by the state was made publicly acceptable at the very moment when the public language was rendered politically correct in order to protect victims from symbolic violence. These two phenomena are two sides of the same coin.

Tinyiko Moluleke (2019:137-156) had added to the list Trump's despicable characterisation of Global South countries as 's-hole countries'.

Žižek's focus on Donald Trump is not only because, as president of the most powerful country in the world, politically, economically and militarily, he has by far the loudest 'bully pulpit' than any other politician in the world. The American Empire, though visibly disintegrating, is like John's vision of the dragon in the Book of Revelation, where it represents the Roman Empire (Boesak [1984] 2015). Even though, in its battle with Michael and the angels, it is on the verge of defeat and going 'to perdition', its tail still has the power to 'sweep down a third of the stars of heaven' and throw them down to the earth ( $R v$ 12:4). One look at the devastation Americans sanctions are causing in Iran and Venezuela, not letting up even in the midst of the devastations of the coronavirus, and how other countries, especially those 
in the European Union, have caved in and flowed suit, is proof enough of this. So, even if he does not mention any of this, Žižek is correct: 'Trump is the purest expression of this tendency towards debasement of our [he means the global community's] public life'. I will argue here that there is much more to this 'tendency'. This is, in fact, the politics of vulgarity, as vital part of the politics of racism, authoritarianism and ethno-nationalism.

The fact that the US president is backing the worst dictatorships in the world today and - as its efforts at regime change in Venezuela show - seeking to create some more is not new. He is simply honouring an imperialistic American exceptionalist tradition, the country that has, since the Second World War, engineered more than 70 regime changes and coup d'etats around the world (Blumenthal 2019; Kinzer 2006). In this, Donald Trump is simply being true to an imperialist tradition followed mercilessly and relentlessly by US presidents for the last 100 years, including the two Bushes, Bill Clinton and Barack Obama.

But more than any occupant of the White House Mr. Trump has used that power to set himself up as a negative 'role model' for other leaders in the world, spurring on and blessing the legitimisation of authoritarianism, racism, bigotry and narrow, violent, ethno-nationalisms. From Rodrigo Duterte's autocratic gangsterist regime in the Philippines to Saudi Arabia's Mohammed Ben Salman's youthful but lethal war-mongering and bloodlust. From Jair Bolsonaro's corrupt dictatorship in Brazil, to Hungary's exclusivist, violent Christian nationalism under Viktor Orban to India's Narendra Modi's equally exclusivist, equally violent Hindu nationalism, to Britain's perfidious Trump clone Boris Johnson. As if to confirm this, Mr. Trump congratulated Mr. Johnson on becoming Britain's Prime Minister, and according to news reports on July 24, 2019, praised Johnson whilst praising himself: 'They like him over there because he is Britain's Trump'.

In this context we should recall that great African American scholar, activist, and Pan-Africanist, W.E.B. DuBois. In 1957, 6 years before his death, in The Ordeal of Mansart, Book One of his still fascinating three-part work, The Black Flame Trilogy, W.E.B. DuBois (1957:257) posed a series of questions that, already challenging in the struggles of his day, would become increasingly so for the times that followed; ours included.

\section{'How shall integrity face oppression?' he asked:}

What shall honesty do in the face of deception? Decency in the face of insult, self-defense before blows? How shall [courage] and accomplishment meet despising, detraction, and lies? What shall virtue do to meet brute force? (DuBois 1957:257).

These are questions, we are discovering, that were not only pertinent to the situation in the United States, from where DuBois was writing and where Dr Martin Luther King Jr. and the black masses of America answered them so magnificently in the Civil Rights struggle. DuBois' voice has been and is still calling to us, everywhere, in every generation. And they were answered by the millions in this country who took their faith seriously, who believed that faith can be a force against injustice and imperialism, and who set the example for new generations in the struggles for indivisible justice, undeniable dignity and inclusive humanity, against the politics of oppression, exploitation and vulgarity.

So with WEB DuBois in mind, one should think of the politics of vulgarity way beyond Donald Trump's predatory misogyny and lethal racism. Let me elaborate. In 2019, Oxfam reported that new billionaires were created every 2 days between 2017 and 2018, whilst every day 1000 people died because of lack of access to basic, affordable healthcare. Now, in its 2020 report, Oxfam states that 'inequality is out of control'. The world's richest $1 \%$ now have twice as much wealth as 6.9 bn people. Twenty-two men own more than $326 \mathrm{~m}$ women in Africa. This represents 'a world of extremes' an inequality crisis 'that remains unaddressed' (Oxfam Report 2020):

This great divide is based on a flawed and sexist economic system that values the wealth of the privileged few, mostly men, more than the billions of hours of the most essential work - the unpaid and underpaid care work done by women and girls around the world. (p. 10)

This does not represent only a financial crisis for the vast majorities of the world, especially in the Global South, and especially women. It is 'a care crisis'. Speaking theologically, Germany's Jürgen Moltmann (1990:190) called it 'a God crisis'. That is what I call the politics of vulgarity.

In 2020, South Africa remains the most unequal society on earth. Over half of our population live in utmost poverty. In the meantime, although for the pampered few, the wealth is piling up. According to a new study released in June 2019 by AfrAsia Bank, Durban, Belito and Umhlanga, with 25\%, have seen the biggest growth in wealth amongst South African billionaires over the past decade, a time period that corresponds nicely with the Zuma/Gupta years. Meanwhile, some of the richest ones - over 3000 - live in the Stellenbosch, Paarl, Franschhoek triangle. Right in my backyard, in other words, and amidst the most appalling poverty on the Western Cape wine farms and the utter misery of the Cape Town 'sink cities' (Vellem's term for Cape Town vast informal settlements) only a few kilometres away (AfrAsia Bank Report 2019).

In a telling investigative piece, Time Magazine's Aryn Baker (2019) wrote about the lessons the world can learn from South Africa as 'worldwide inequality grows'. Despite the worldwide euphoria and the iconisation of Nelson Mandela, for South Africa's poor, black majority, 'very little has changed', Kenny Tokwe from affluent Hout Bay's black informal settlement Imizamo Yethu, tells her. Baker wrote in 2019 what most black South Africans have known for the most part of the last 25 years: the world's most egregious racial divide has turned into its most extreme economic disparity. According to the World Bank 2015 calculations the 
top $10 \%$ (mostly white) owned $70 \%$ of the nation's wealth, whilst half of the population lives on less than $\$ 5$ a day. So, what is the lesson the world can learn from South Africa today?

In an age of widening divisions between rich and poor South Africa stands out because of its squandered hopes (Baker 2019).

This situation angered Vuyani Vellem. He spoke of the 'SantaClausification' of South Africa's democracy. The 'post-1994 settlement became a foreign and fraudulent discourse [which] should be the starting point of the analysis of democracy on South Africa' (Vellem 2017:13). But his righteous anger is not rooted in mindless rage, nor in cold analysis of the situation. Rather it is rooted in his blackness, in other words, in the sharing of the pain, experiences and ongoing destruction of his people. He quotes Itumeleng Mosala (Maldonado-Torres 2016):

The black pain of a post-apartheid betrayal is infinitely more painful and dangerous than that of an age when no one had promised freedom to anyone ... As the Yanks would say, 'It is coloniality, stupid!' No need for a doctorate to grasp this. Blackness should be enough! (Vellem 2017:10).

Vuyani repeats the phrase, 'Blackness should be enough!'

And therein lies the politics of vulgarity: the squandering of the hopes of the masses who struggled for freedom, who sacrificed endlessly and gave their lives and who believed in the African National Congress and the trustworthiness of its leaders, including Nelson Mandela. And in this the blackness of our ruling class, despite their claims upon it when it is expedient, is clearly not enough. One's blackness counts for nothing if it is not identification with the suffering of the black poor, the oppressed and the leftbehind. It is not only coloniality, but this subservience to it, the profiting from it, that remains 'the festering wound' (Vellem 2017:10).

Throughout 2019, at the US' southern border, parents and children were being separated, almost half of those have not yet found each other. Babies, toddlers and young children are left to die in those concentration camps the Trump administration calls 'border facilities'. Those children lucky enough to survive, are still there, sleeping on concrete floors, not allowed a shower as they have come across the border, no soap, no clean clothes and miserable food. This treatment, a report says, is brutal by design. Those wanting to help them are turned away at the gates by border guards. A young teacher from Arizona, Scott Warren, has been arrested, charged and brought to trial where he faces 20 years in prison. His crime? He gave food and water to immigrants wandering through the desert, hoping to reach the US. Indeed, in the US right now, saving lives is a crime. The fact that he was finally acquitted does not change the vulgarity of the politics involved here (Deveraux 2019).
But, and for Christians this is the point, Mr Trump is in power because $81 \%$ of white evangelicals in the US voted for him in 2016. He is what white evangelical Christian America wants. People of good will in the United States are struggling, like we are here, to give their country a human face and Christians are in the forefront of trying to keep it on that 'far, distant horizon'. But these Christians are not committed to peace and justice, to equity, dignity and an inclusive humanity. They are, what African American Judge and pastor Wendell Griffen $(2017: 7,42,74,137)$ calls 'the hateful faithful'. ${ }^{9}$

In June 2019, Franklin Graham, son of the late evangelist Billy Graham and today one of the front leaders and foremost spokesperson for the American white evangelical right, called for a Day of Prayer for President Trump. Graham gave his reasons: the president was under severe attack from enemies of the president and the US, who, by the same token, are also enemies of the faith (Morton 2019).

It might be useful to ask who these enemies of Trump and the faithful in the United States are. They are the people who are against the endless wars the United States is waging in no less than eight Muslim countries as I write; people against his embrace of the murderous regime in Saudi Arabia (also a fundamentalist religious regime) who last year beheaded 47 of its citizens because they oppose the house of Saud ${ }^{10}$ (The Guardian 2018). These are the people against his immigration policies, against the concentration camps along the US southern border. The enemies of the faith are those against sanctions against Venezuela that have taken the lives of more than 40000 people since 2017. It is those people who stand in the breach for LGBTQI persons against whom the Trump administration has waged a virtual war at every level and those against the propping up of the murderous apartheid regime in Israel and the illegal and deadly colonisation of Palestine.

I am not even speaking of the Russians, the Chinese, the Latin Americans, the Mexicans, all those 'rapists', 'criminals' and 'drug dealers' who 'invade' the United States, and the millions of 'bad Muslims' as Mahmood Mamdani calls them (See Mamdani 2004), who refuse to bend to America's will, as opposed to the 'good Muslims' who do. So finally, Christians can rid themselves of that pesky, silly command of Jesus to love our enemies: there are simply too many of them. Who can keep up? As such, they are, as Naomi Klein (2007:163ff.) called them, 'useful enemies'. Useful, and indispensable for the purposes of the politics of fear mongering, intimidation and authoritarianism, but easily dispensable nonetheless.

I have written this article when there was no sign of a thing called the coronavirus (COVID-19) nor of the chaos it would cause worldwide, nor of the way it would unmask the politics of vulgarity on a global scale such as we are now experiencing 9.The title of a forthcoming book by Wendell Griffen.

10. Human rights activists fear that these are excuses for punishing persons who oppose the House of Saud. 
as I write. We have already seen the shameless heart of neoliberal capitalism. It is Naomi Klein's 'disaster capitalism' at its worst. The blatant profiteering from the illness, the carelessness of the ill-preparedness for which world leaders such as Donald Trump refuse to take responsibility. The endless politicisation of the pandemic for selfish political gain. Mr. Trump's trying to detract from his own mishandling of the crisis by blaming the WHO and openly threatening to cut US funding from the UN organ, is one of the worst instances of where this is taking us. But even this topped by the Hitleresque suggestion by Texas Lt. Governor Dan Patrick that elderly Americans should disregard the risks to their health and their lives, go to work, to save the American economy.

And look where that mindless vulgarity has taken the world: foreign policies characterised by bullying instead of respectful negotiation; forceful capitulation instead of common understanding; enforced submission instead of equal partnership; reckless lawlessness instead of respect for international law. Rabid ethnic and religious nationalism instead of inclusive global security, and xenophobic rage instead of an understanding of our common humanity. Imperialist expansionism instead of peaceful coexistence; destructive, unbridled neoliberal capitalist exploitation instead of planetary security; internationalised thuggery instead of the promotion and protection of human rights and nationalistic vanity instead of global servanthood. It is a form of international political vandalism.

Meanwhile, we'll have to grapple with the painful truth that whilst the resilience of religion has proved Harvey Cox (1965) wrong and is playing a larger, more determining role in public life than our post-modern age has ever seen; ${ }^{11}$ yet the politics of solidarity, decency, integrity and virtue has been swallowed entirely by the politics of vulgarity. By overwhelming levels of abusive power, craven cowardice, untamed voraciousness, unrepentant racism, shameless bigotry and unending violence.

So it is clear that the world does not yet have that human face. Neither does South Africa. Behind the coronavirus masks we are now required to wear to help save our lives, are hidden the masks that cover infections that will outlast the infections of COVID-19 and that threaten our soul. Behind the arrogant mask of self-satisfied power, behind the smug smiles of greed and instant gratification; behind the self-congratulatory mask of rainbow-nationism, we hide the grim realities of our immoral and unsustainable inequalities, our poverty, suffering and abuse, which is the face of the poor, the vulnerable, the women, the girl-children and the forgotten.

In South Africa, the coronavirus crisis has been admirably handled by President Ramaphosa's government, and as

11.Twenty-five years later, Cox admitted that he was wrong in an interview 25 years later, Harvey Cox admits that 'human religiosity is a much more persistent quality ... Nearly everywhere we look in the world today we witness an unanticipated resurgence of traditional religion' (see Cox 1990). president, he has acquitted himself of this task with political responsibility, firm resolve, dignified leadership and honest compassion. South Africans should be grateful for such leadership in these times of unprecedented and terrifying crises. It would serve us well however, to remember that the fundamental fault lines in South African society as we discussed here, have preceded the problems we now face, have in fact exacerbated them. The genuine concern for the safety of the poorest of the poor is understandable and admirable, but unless these issues are seriously and urgently addressed with no less than a fundamental change in economic policies, political behaviour and moral discernment, the next crisis will find us confronting the same problems, only worse. And after we have won this current battle, we are still confronted with Jesus' question: 'But what will it profit them if they gain the whole world and lose their soul? [forfeit their life?]' (Mt 16:28).

\section{The human face and spirituality}

Was the deepest heart of Biko's search for our human face, a search for a true African spirituality? I suggest it was. As Biko discusses his 'quest for a true humanity', he is careful to situate it in the context of both liberation and spirituality. African spirituality, he argues has what the Western world, despite its many material accomplishments, does not have, and sorely needs: 'the dimension of the spiritual'. This is what will give the world a human face (Biko 2017:51).

Like Biko, Vellem (2007) never separated spirituality from freedom. Liberation, in both, remains key. He speaks of 'the spirituality of liberation' and of spirituality as an anti-dote to 'ideology'. Spirituality, for him, is 'the symbol of liberation in South African public life'. He argues strenuously for the continuation of the struggle for liberation as a struggle for life, despite the cultural pressures of the immediate post-1994 era (Vellem 2007, 2014), and the temptations of the pretence of freedom (Vellem 2017:6-9).

Like Biko, he believed that to do this we need a living, vibrant black theology of liberation, to combat 'the internal logic of Western superiority and debunk it' (Vellem 2014). Insistently, he rails against the 'co-opting' of African spirituality under the new liberal-speak guise of 'inclusion' It is not genuine inclusion, he argues, but rather 'a vexing cosmetic use of African values and a refusal of the death of consciousness' (Vellem 2014).

Still, Vuyani Vellem (2017:15) lived the hope he preached and taught. His 'embers' become 'echoes of fire' because of the vibrancy and resilience of African spirituality. 'There is a revival going on', he writes. 'An Imvuselelo, a throng of singing, dancing and the preaching masses'. It is a hope shared by the struggling masses in the world with a tenacity that is both astonishing and life-giving. The Oxfam Report (2020:18-19), even as it sets out the grim realities of our global situation, has caught something of this as it states, repeatedly, 
that 'a fairer world is possible'. But a fairer world, that is, a more just and equitable, peaceful world, the report also insists throughout, must be 'a feminine world'. ${ }^{12}$ For without women claiming and having their rightful place in the world, without women enjoying their full humanity in an inclusive, indivisibly just human community, this hope remains forlorn. Our human face remains 'far, on the distant horizon'. Perhaps this understanding turned into practical policies, making the politics of justice and dignity 'habits of the heart' (Bellah et al. 1985) might be Africa's gift to the world and so fulfilling Biko's hope.

As a woman, Arundhati Roy must have understood Biko as well, as she understands our global struggle. We are in a struggle, 'confronting empire', she writes. In this fight, we have already won major victories, and we must claim them. We must find hope and courage in the fruits of our agency and our victories. Every step forward counts.

We ... have, each in our way, laid siege to Empire. We may not have stopped it in its tracks yet but we have stripped it down. We have made it drop its mask. We have forced it into the open. It now stands before us on the world's stage in all its brutish, iniquitous nakedness ... too ugly to behold its own reflection (Roy 2013).

In confronting empire, she knows, we must understand that we cannot enter this fight without the fortitude of our spirituality. We must not only confront empire. We must, in the midst of the clamour of war, the shouts of arrogance and the cries of pain and suffering, also fight for the quiet moments. Vuyani Vellem's imvuselelo is that fight which makes it possible for us to believe that 'Another world is not only possible, she is on her way. On a quiet day, I can hear her breathing' (Roy 2013).

\section{Acknowledgements Competing interests}

The author declares that he has no financial or personal relationships that may have inappropriately influenced him in writing this research article.

\section{Author's contributions}

A.A.B. is the sole author of this research article.

\section{Ethical consideration}

This article followed all ethical standards for research without direct contact with human or animal subjects.

\section{Funding information}

This research received no specific grant from any funding agency in the public, commercial or not-for-profit sectors.

12.The Oxfam Report's entire focus on women and girls and their place in the global
economy in order to make it a fairer economy is necessary, justified and completely convincing.

\section{Data availability statement}

Data sharing is not applicable to this article as no new data were created or analysed in this study.

\section{Disclaimer}

The views and opinions expressed in this article are those of the author and do not necessarily reflect the official policy or position of any affiliated agency of the author.

\section{References}

Afrasia Bank Report, 2019, viewed 25 May 2020, from https://www.afrasiabank.com/ en/about/newsroom/south-africa-wealth-report-2019.

Baker, A., 2019, 'What South Africa can teach us as worldwide inequality grows', Time Magazine, 02 May 2019, viewed 25 May 2020, from https://time.com/longform/ south-africa-unequal-country.

Bellah, R.N., Madsen, R., Sullivan, W.M. \& Swidler, A., 1985, Habits of the heart, individualism and commitment in American life, University of California Press, Berkeley, CA.

Biko, S., 2017, I write what I like, 40th anniversary edn., Picador Africa, Johannesburg.

Blumenthal, M., 2019, The management of savagery: How America's security state fueled the rise of Al Qaeda, ISIS, and Donald Trump, Verso, New York, NY.

Boesak, A.A., 1976, Farewell to innocence, a socio-ethical study of black theology and black power, Orbis, Maaryknoll, NY.

Boesak, A.A., [1984] 2015, Comfort and protest, the apocalypse from a South African perspective, Wipf \& Stock, Eugene, OR

Boesak, A.A., 2009, Running with horses, reflections of an accidental politician, Joho!, Cape Town.

Boesak, A.A., 2017, Pharaohs on both sides of the blood-red waters, prophetic critique on empire, resistance, justice and the power of the hopeful Sizwe. A transatlantic conversation, Cascade, Eugene, OR.

Boesak, A.A., 2019, Children of the waters of Meribah, black liberation theology, the Miriamic tradition, and the challenges of 21st century Empire, Cascade, Eugene, OR.

Calvin, J., 1981, Commentaries, 22 vol., transl. and edited by J. King et al., Baker, Grand Rapids, MI.

Clarke, S., Manchala, D. \& Peacock, P. (eds.), 2017, Dalit theology in the twenty-first century, Oxford University Press, New Delhi.

Cox, H., 1965, The secular city, secularization and urbanization in theological perspective, Princeton University Press, Princeton, NJ.

Cox, H., 1990, The secular city 25 years later, viewed 25 May 2020, from https://www. religion-online.org/article/the-secular-city-25-years-later.

Deveraux, R., 2019, 'Humanitarian volunteer Scott Warren reflects on the borderlands and two years of government persecution', The Intercept, 23 November 2019 viewed 25 May 2020, from https://theintercept.com/2019/11/23/scott-warrenverdict-immigration-border/.

Douglass, F., 1857, If there is no struggle, there is no progress, A 'West India Emancipation' speech delivered at Canandaigua, New York, NY, viewed n.d., from https://www. speech delivered at Canandaigua, New blackpast.org/?s=If+there+is+no+struggle $\% 2 \mathrm{C}+$ there+is+no+progress.
b.

DuBois, W.E.B., 1957, The book of Mansart, III, Mainstream, New York, NY.

Erasmus, Z., 2018, “'Race" and its articulation of the human', in N.G. Jablonski \& G. Mare (eds.), The effects of race, pp. 53-68, 58-59, Sun Press, Stellenbosch.

Griffen, W., 2007, The fierce urgency of prophetic hope, Judson Press, King of Prussia, Upper Merion Township, PA.

Human Rights Watch, 1999, Broken people: Caste violence against India's 'untouchables', pp. 1-2, Human Rights Watch, New York, NY.

Johnson, W., 2017, 'No rights a white man is bound to respect', Boston Review, A political and literary forum, viewed 27 September 2017, from http://bostonreview.net/lawjustice/walter-johnson-no-rights-which-white-man-bound-respect.

Kinzer, S., 2006, Overthrow: America's century of regime change from Hawai'i to Iraq, Henry Holt, New York, NY.

Klein, N., 2007, The shock doctrine, the rise of disaster capitalism, Henry Holt, New York, NY.

Mamdani, M., 2004, Good Muslim, bad Muslim: America, the cold war, and the roots of terror, Pantheon Publishers, New York, NY.

Maldonado-Torres, N., 2016, Outline of ten theses on coloniality and decoloniality, viewed 25 May 2020, from www.caribbeanstudiesassociation.org/docs/ Maldonado-Torres_Online_Ten_Theses_10.23.16pdf.

Moltmann, J., 1990, God for a secular world, the relevance of theology, Fortress, Minneapolis, MN.

Moluleke, T., 2019, 'Africans alienated inside and outside', Journal of Theology in Southern Africa 162-163, 137-156.

Morton, V., 2019, Franklin Graham calls for a 'special day of prayer' for Trump: 'This is a critical time for America', viewed 25 May 2020, from https://www. washingtontimes.com/news/2019/may/27/franklin-graham-calls-donald-trumpspecial-day-pra/. 
Oxfam Report, 2020, viewed 25 May 2020, from https://oxfamilibrary.openrespository. $\mathrm{com} / \mathrm{bitstream} / \mathrm{handle} / 10546 / 620928 / \mathrm{bp}$-time-to-care-inequality-200120-en pdf.

Paraskewa, J.M. (ed.), 2016, The curriculum: Whose internationalization?, Peter Lang, New York, NY.

Roy, A., 2013, Confronting empire, viewed 25 May 2020, from https://ratical.org/ ratville/CAH/AR012703.html.

Sesanti, S., 2016, 'Afrocentric education for an African renaissance, philosophical underpinnings', New Agenda, South African Journal of Social and Economic Policy 2016(62), 34-40.

Smith, M.N. \& Tivaringe, T., 2016, 'From Afro-centrism to decolonial humanism and Afro-plurality: A response to Simphiwe Sesanti', New Agenda, South African Journal of Social and Economic Policy 62(1), 41-43.

The Guardian, 2018, viewed 25 May 2020, from https://amp.theguardian.com/ world/2018/apr/26/saudi-arabia-criticised-over-executions-for-drug-offences.
Vellem, V., 2007, Symbol of liberation in South African public life: A black theological perspective, viewed 25 May 2020, from https://www.semanticscholar.org/paper/ The-symbol-of-liberation-in-South-African-public-\%3A-Vellem/1c93d1d940e6fca b3a38107fbf16a77381a3c107.

Vellem, V., 2010, 'Ideology and spirituality: A critique of Villa-Vicencio's project of reconstruction', Scriptura 105, 547-558. https://doi.org/10.7833/105-0-156

Vellem, V., 2014, 'Spirituality of liberation: A conversation with African religiosity', HTS Theological Studies 70(1), 7. http://doi.org/10.4102/hts.v70i1.2752

Vellem, V.S., 2017, 'Unthinking the West: The spirit of doing Black Theology of Liberation in decolonial times', HTS Theological Studies 73(3), a4737. https://doi. org/10.4102/hts.v73i3.4737

Villa-Vicencio, C., 1983, 'An all-pervading heresy', in C. Villa-Vicencio \& J. De Gruchy (eds.), Apertheid is a Heresy, pp. 59-74, David Philip, Cape Town.

Žižek, S., 2016, 'The return of public vulgarity', Newsweek, 02 December 2016, viewed 25 May 2020, from https://newsweek.com/return-public-vulgarity-425691. 